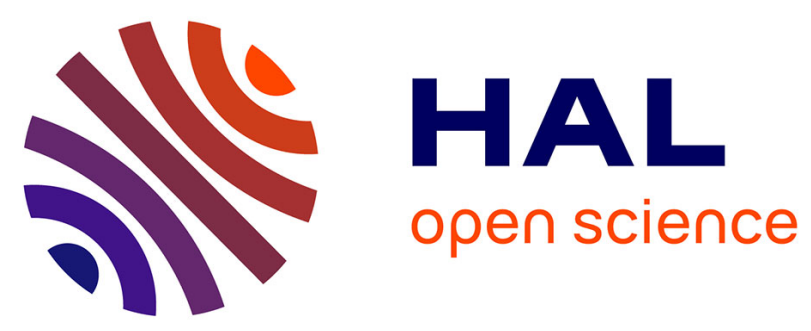

\title{
Morphological adaptation with preserved proliferation/transporter content in the colon of patients with short bowel syndrome
}

Francisca Joly, Camille Mayeur, Bernard Messing, Anne Lavergne-Slove, Dominique Cazals-Hatem, Marie-Louise M.-L. Noordine, Claire C. Cherbuy, Pierre-Henri Duée, Muriel M. Thomas

\section{To cite this version:}

Francisca Joly, Camille Mayeur, Bernard Messing, Anne Lavergne-Slove, Dominique Cazals-Hatem, et al.. Morphological adaptation with preserved proliferation/transporter content in the colon of patients with short bowel syndrome. AJP - Gastrointestinal and Liver Physiology, 2009, 297 (1), pp.G116-G123. 10.1152/ajpgi.90657.2008 . hal-02668647

\section{HAL Id: hal-02668647 https://hal.inrae.fr/hal-02668647}

Submitted on 31 May 2020

HAL is a multi-disciplinary open access archive for the deposit and dissemination of scientific research documents, whether they are published or not. The documents may come from teaching and research institutions in France or abroad, or from public or private research centers.
L'archive ouverte pluridisciplinaire HAL, est destinée au dépôt et à la diffusion de documents scientifiques de niveau recherche, publiés ou non, émanant des établissements d'enseignement et de recherche français ou étrangers, des laboratoires publics ou privés. 


\title{
Morphological adaptation with preserved proliferation/transporter content in the colon of patients with short bowel syndrome
}

\author{
Francisca Joly, ${ }^{1}$ Camille Mayeur, ${ }^{2}$ Bernard Messing, ${ }^{1}$ Anne Lavergne-Slove, ${ }^{3}$ Dominique Cazals-Hatem, ${ }^{4}$ \\ Marie-Louise Noordine, ${ }^{2}$ Claire Cherbuy, ${ }^{2}$ Pierre-Henri Duée, ${ }^{2}$ and Muriel Thomas ${ }^{2}$ \\ ${ }^{1}$ Service de Gastroentérologie et Assistance Nutritive, Pôle des Maladies de l'Appareil Digestif and ${ }^{4}$ Service \\ d'Anatomo-pathologie, Hôpital Beaujon, Clichy; ${ }^{2}$ Unité d'Ecologie et de Physiologie du Système Digestif, UR 910, Institut \\ National de la Recherche Agronomique, Jouy en Josas; ${ }^{3}$ Service d'Anatomo-pathologie, Hôpital Lariboisière, Paris, France
}

Submitted 16 November 2008; accepted in final form 2 April 2009

\begin{abstract}
Joly F, Mayeur C, Messing B, Lavergne-Slove A, Cazals-Hatem D, Noordine ML, Cherbuy C, Duée PH, Thomas M. Morphological adaptation with preserved proliferation/transporter content in the colon of patients with short bowel syndrome. Am J Physiol Gastrointest Liver Physiol 297: G116-G123, 2009. First published April 23, 2009; doi:10.1152/ajpgi.90657.2008.- - In short bowel syndrome (SBS), although a remaining colon improves patient outcome, there is no direct evidence of a mucosal colonic adaptation in humans. This prospective study evaluates morphology, proliferation status, and transporter expression level in the epithelium of the remaining colon of adult patients compared with controls. The targeted transporters were $\mathrm{Na}^{+} / \mathrm{H}^{+}$exchangers (NHE2 and 3) and oligopeptide transporter (PepT1). Twelve adult patients with a jejuno-colonic anastomosis were studied at least $2 \mathrm{yr}$ after the last surgery and compared with 11 healthy controls. The depth of crypts and number of epithelial cells per crypt were quantified. The proliferating and apoptotic cell contents were evaluated by revealing Ki67, PCNA, and caspase-3. NHE2, NHE3, PepT1 mRNAs, and PepT1 protein were quantified by quantitative RT-PCR and Western blot, respectively. In patients with SBS compared with controls, 1) hyperphagia and severe malabsorption were documented, 2) crypt depth and number of cells per crypt were $35 \%$ and $22 \%$ higher, respectively $(P<0.005)$, whereas the proliferation and apoptotic levels per crypt were unchanged, and 3) NHE2 mRNA was unmodified; NHE3 mRNA was downregulated near the anastomosis and unmodified distally, and PepT1 mRNA and protein were unmodified. We concluded that, in hyperphagic patients with SBS with severe malabsorption, adaptive colonic changes include an increased absorptive surface with an unchanged proliferative/apoptotic ratio and well-preserved absorptive NHE2, NHE3, and PepT1 transporters. This is the first study showing a controlled nonpharmacological hyperplasia in the colon of patients with SBS.
\end{abstract}

nutrition; colonic hyperplasia; proliferation markers; Ki67; PCNA; caspase-3; $\mathrm{Na}^{+} / \mathrm{H}^{+}$exchanger 3 ; $\mathrm{Na}^{+} / \mathrm{H}^{+}$exchanger 2 ; PepT1; hyperphagia

THE NORMAL HUMAN SMALL INTESTINE length is generally considered to be between 3 and $8 \mathrm{~m}$ from the duodenojejunal flexure to the ileocecal valve. In adults, the massive resection of the small bowel leaving less than $200 \mathrm{~cm}$ of small bowel defines short bowel syndrome (SBS), and a small bowel length of $<100 \mathrm{~cm}$ is highly predictive of permanent intestinal failure (8, 31). SBS includes clinical signs characterized by diarrhea, dehydration, malabsorption of macronutrients, weight loss, malabsorption of vitamins and trace elements, and malnutrition $(2,37)$. In patients with SBS, the degree of malabsorption depends on the area and site of the resection as well as any

Address for reprint requests and other correspondence: F. Joly, Service de Gastroentérologie et Assistance Nutritive, Pôle des Maladies de 1'Appareil Digestif, Hôpital Beaujon, Clichy, France (e-mail : francisca.joly@bjn.aphp.fr). persistence of damage within the remnant bowel. Patients with SBS type I had a jejunostomy, whereas patients with SBS type II had an anastomosis between jejunum and colon.

After massive reduction of the small bowel in animal models, the remnant intestine shows functional changes and significant morphological changes, i.e., hyperplasia, to compensate for absorptive functions in both the small bowel and the colon $(18-20,27,44,48)$. These changes are called adaptive and are mainly dependent on enteral neuro-hormonal stimuli (53). This adaptive phase occurs between the postoperative and sequela phases both in animals and humans. In humans, an adaptive process has never been convincingly demonstrated in the remnant small or large intestine $(3,39,41)$. At the colonic level, absorptive changes in humans are significant through hyperfermentation of malabsorbed carbohydrates attributable to changes in the bacterial microflora (7). Indeed, clinical experience indicates that patients with short bowel with a jejuno-colonic anastomosis (SBS type II) show improved absorption capacity with time, whereas patients with end-terminal jejunostomy without colon (type I) do not $(12,31)$, and the presence of remaining colon is associated with a lower dependence of a supply with parenteral nutrition (PN) $(31,35)$. Although the presence of the colon is an important determining factor in the clinical SBS outcome, with a better outcome than type I SBS $(36,51)$, direct proof of mucosal colonic adaptive changes have not been demonstrated except for one study showing an increase in $\mathrm{H}^{+}$-coupled oligopeptide transporter (PepT1) in the remaining colon (55).

The aim of this prospective study was to evaluate the nutritional status and the adaptive changes of the remaining colon of SBS adult patients, at least two years after resection, compared with healthy controls.

\section{MATERIALS AND METHODS}

A prospective case-control study was performed. The Human Investigations Committee of Saint Louis Hospital-Paris approved the study (no. 031048).

\section{Patients}

Inclusion criteria of patients with SBS were 1) SBS type II with a postduodenal remnant jejunum $<150 \mathrm{~cm}$, no remnant ileum and reestablished jejuno-colic continuity for more than $2 \mathrm{yr}, 2$ ) a nonrestricted oral diet, and 3) a normal colonoscopy of the remaining colon. All patients received gastric antisecretory drugs, but none had pancreatic enzyme treatment. Exclusion criteria were 1) upper gastrointestinal tract surgery (esophagus, stomach, duodenum, and/or pancreas), 2) a remnant ileum, 3) radiation enteritis and active Crohn's disease, 4) organ failure other than gastrointestinal, 5) evolutive neoplasia, 6) intestinal fistulae, 7) treatment by recombinant human 
growth hormone or glucagon like peptide-2 in the last $12 \mathrm{mo}, 8$ ) body mass index $(\mathrm{BMI})>30,9)$ age $>80$ or $<18 \mathrm{yr}$ old, 10) sepsis and/or antibiotics or aspirin in the $4 \mathrm{wk}$ before the study, 11) treatments with steroids or immunosuppressive therapy in the 4 mo preceding the study, and 12) pregnancy. Reconstructive surgery of the remnant small bowel such as a reversed distal jejunal loop was not an exclusion criteria (31). The remaining colon in continuity, expressed in terms of percent of the usual length according to the method of Cummings et al. (13), was estimated on the basis of preoperative records. Routine biological data included serum albumin, transthyretin, and $\mathrm{C}$ reactive protein $(\mathrm{CRP})$ blood levels.

\section{Control Group}

Participants were recruited among outpatients with an indication for colonoscopy for colon cancer screening or evaluation of abdominal pain. Control subjects were selected if they were clinically stable with no change in weight of more than $5 \%$ in the last 6 mo and had no previous history of gastrointestinal or systemic diseases. Other exclusion criteria included 1) $\mathrm{BMI}>30,2)$ age $>80$ or $<18$ yr old, 3) sepsis and/or drugs in the 4 wk before the study, and 4) pregnancy. Inclusion criteria were a normal colonoscopy with normal histology sampling.

\section{Absorption Study}

Patients with SBS underwent a metabolic study to evaluate intestinal macronutrient absorption as described (32). Briefly, over a 6-day period, the first 3-day equilibrium period confirmed that patients were continuing their spontaneous intake of energy, carbohydrates, lipids, proteins, and fibers, and the absorption was measured the last 3 days. Unrestricted intake was measured by amount or weight and calculated with Bilnut software (Bourgerette P, Rolshansen M; BILNUT 4.0; SCDA Nutrisoft, Cerelles, France). Stools were collected daily and frozen at $-20^{\circ} \mathrm{C}$. Protein, lipid, and total energy were determined by nitrogen elemental analysis ( $\mathrm{N}$ analyser Flash EA1112; Thermo Scientific, Waltham, MA) (26) and the method of Van de Kamer and bomb calorimetry (PARR 1351 bomb calorimeter; Parr Instrument, Moline, IL) (33), respectively. Quantification of carbohydrate-derived energy was calculated by subtracting the energy associated with the protein and lipid components from the total energy. The calorieconversion factors used were $4.2,9.35$, and $5.65 \mathrm{kcal} / \mathrm{g}$ for carbohydrates, lipids, and proteins, respectively (47). The coefficient of net intestinal absorption represented the proportion of ingested energy not recovered in stool output.

\section{Endoscopy and Mucosal Biopsy Specimens}

To obtain tissue for histological analysis, patients and controls were submitted to routine bowel preparation with poly-ethylene-glycol the evening before colonoscopy with no change in dietary habits. Colonoscopy and colonic biopsies were performed in patients with SBS after the metabolic study. Three biopsies, allowed by the Human Investigations Committee, were obtained in the middle segments of remaining colon, i.e., proximal (or right colon), transverse, and distal colon (or left colon), respectively.

\section{Analysis of Colonic-mucosal Morphology and Detection of Ki67 by Immunohistochemistry}

All colonic biopsies were fixed in formalin for $24 \mathrm{~h}$, embedded in paraffin, and analyzed on hematoxylin-eosin-safran-stained slides. Determination of epithelial cells and of depths of crypts were assessed by a senior gastrointestinal pathologist who was blind to the clinical findings (A. Lavergne-Slove) using a light microscope equipped with a calibrated ocular micrometer; each longitudinal hemicrypt was divided into three equal-sized compartments from the muscularis mucosa to the surface. The quantifications required the full length of at least three well-oriented colonic crypts; this condition was obtained in eight patients with SBS and seven controls. Immunohistochemistry was performed on deparaffinized formalin-fixed tissues sections (5 $\mu \mathrm{m})$ using Ki67 antibody (clone Mib1; Dakocytomation, Glostrup, Denmark), and a histostainer automat (Nexes; Ventana, Tucson, AZ). The proliferative index of the mucosa was calculated by dividing the number of Ki67-labeled cells by the total number of cells and expressing the results as a percentage.

\section{Detection of Caspase-3 by Immunohistochemistry}

Caspase-3 immunohistochemistry was performed on deparaffinized formalin-fixed tissue sections $(5 \mu \mathrm{m})$ with a rabbit monoclonal antibody against active caspase-3 (clone C92-605; BD Pharmingen, San Diego, CA) using a histostainer automat (Ventana). Caspase-3-positive cells were quantified as the higher number of positive colonic superficial cells observed between six crypts ( $\times 200$ magnification), in eight patients with SBS and eight controls.

\section{RNA Extraction and Real-time PCR Analysis}

Frozen biopsy samples were homogenized using the TissueLyser (Retsch; Qiagen, Valencia, CA) for $5 \mathrm{~min}, 25 \mathrm{~Hz}$ in $1 \mathrm{ml}$ Trizol reagent (TRIzol reagent; Invitrogen, Carlsbad, CA), and RNAs were isolated using the phenol-based extraction method (10). RNA concentration and purity were confirmed by absorbance measurement, using a Biophotometer (Eppendorf, Westbury, NY). In our experiment, A260:A280 ranged from 1.8 to 2.0, which is considered to be an acceptable indicator of RNA purity. An RNA integrity number (RIN) was also determined with the Agilent 2100 bioanalyzer (Agilent Technologies, Santa Clara, CA) and the RNA 6000 nano LabChip kit. The RINs did not exceed 5 in either biopsy. Because the RINs were close, samples were compared together as in Imbeaud et al. (23).

One microgram of the total RNA samples was subjected to a reverse transcription step in a 50- $\mu$ l final volume using the highcapacity cDNA archive kit (Applied Biosystems, Foster City, CA). Single-stranded cDNA products were analyzed by real-time PCR using TaqMan Gene Expression Assays (Applied Biosystems). Single-stranded cDNA products were analyzed with the ABI PRISM 7000 Sequence Detection System (Applied Biosystems). Four genes were analyzed including: the eukaryotic 18S rRNA (Hs99999901_s1), the human NHE3 gene (SLC 9A3, Hs00188200_m1), the human NHE2 gene (SLC 9A2, Hs00268166_m1), and the human PEPT1 gene (SLC 15A1, Hs00192639_m1). After we tested several housekeeping genes, eukaryotic 18S rRNA was used as a reference gene because of its stability in the different colonic segments between patients and controls. In each case, triplicate cycle $(\mathrm{Ct})$ values were obtained and averaged. The fold change in one target gene was normalized to the eukaryotic $18 \mathrm{~S}$ rRNA.

\section{Protein Extraction and Western Blot Analysis}

Biopsies were disrupted with a tissue lyser in RIPA buffer, and total proteins were quantified using the Lowry method. Proteins were extracted from subconfluent HT-29 and Caco-2 line cells. Different amounts of proteins were loaded into a $10 \%$ SDS-polyacrylamide gel and then electrotransferred. PCNA and PepT1 were respectively revealed by a monoclonal antibody (Upstate Biotechnology, Lake Placid, NY) at a 1:1,000 dilution and by a polyclonal antibody (H-235; Santa Cruz Biotechnology, Santa Cruz, CA) at a 1:200 dilution. All membranes were stripped and rehybridized with an antibody against GAPDH $(1: 5,000)$ (Euromedex, Souffelweyersheim, France). An anti-mouse $(1: 12,000)$ or an anti-rabbit $(1: 5,000)$ antibody (Jackson ImmunoResearch Laboratories, Bar Harbor, ME) conjugated with peroxidase was used to detect immune complexes by chemiluminescence using the ECL + detection system (Amersham Pharmacia Biotech, St. Giles, UK). Systematically, a protein ladder was loaded, and the weight of the band was checked. Autoradiography films were quantified using the Las1000 camera system (Fujifilm, 
Table 1. Clinical characteristics of patients with SBS

\begin{tabular}{|c|c|c|c|c|c|}
\hline Patient (sex) & $\begin{array}{l}\text { Age When } \\
\text { Studied, yr }\end{array}$ & $\begin{array}{l}\text { Delay Since Continuity } \\
\text { Restablishment, yr }\end{array}$ & Diagnosis & $\begin{array}{l}\text { Remnant Small Bowel } \\
\text { Length, cm }\end{array}$ & Remnant Colon, \% \\
\hline P1 (F) & 52 & 11 & mesenteric infarction & 0 & 70 \\
\hline P2 (M) & 51 & 4 & mesenteric infarction & 10 & 50 \\
\hline $\mathrm{P} 4(\mathrm{~F})$ & 69 & 4 & mesenteric infarction & 15 & 80 \\
\hline P5 (F) & 45 & 2 & mesenteric infarction & 20 & 80 \\
\hline P6 (M) & 56 & 18 & mesenteric infarction & 30 & 40 \\
\hline P10 (M) & 49 & 12 & Crohn's disease & 60 & 50 \\
\hline P11 (F) & 71 & 9 & volvulus & 80 & 50 \\
\hline P12 (F) & 60 & 19 & mesenteric infarction & 100 & 80 \\
\hline Means $\pm S D$ & $54 \pm 8$ & $9 \pm 5$ & & $32 \pm 30$ & $60 \pm 19$ \\
\hline
\end{tabular}

Patients were numbered (from 1 to 12 ) according to the remnant postduodenal jejunal length (cm). Delay was in years from the last surgery establishing an anastomosis between the jejunum and the remaining colon. The length of the remaining colon in continuity was expressed in percent of the usual length (13). SBS, short bowel syndrome; F, female; M, male.

Paris, France) and the Aida software (Raytest, Paris, France). The quantitative data (arbitrary unit) were calculated for each lane by dividing the signal of PepT1 by the signal of loading control.

\section{Statistical Analysis}

Statistical analysis was performed using the Statview software (version 5; SAS Institute, Cary, NC). The comparison between the control group and patients (means \pm SD) for age, BMI, oral intake, crypt depth, and number of cells per crypts was analyzed using a Student's $t$-test. $1 / \Delta \mathrm{Ct}$ values of RT-PCR were compared at each site (proximal, transverse, and distal) between control group and patients with a Mann-Whitney test. Level of significance was a $P$ value $<0.05$.

\section{RESULTS}

\section{Characteristics of Patients with SBS and Controls}

After obtaining written consent for the protocol, 12 patients with SBS and 14 controls were screened and eligible between January 2004 and September 2006.

Clinical characteristics of adult patients with SBS are listed in Table 1. All patients with SBS had a normal colonic mucosal histology. Etiology of SBS was arterial mesenteric infarction $(n=10)$, volvulus $(n=1)$, and Crohn's disease $(n=1)$ with no residual lesions of the remnant intestine. The only patient with Crohn's disease was in clinical remission without specific treatment for more than one year. The study was performed $9.0 \pm 5.6 \mathrm{yr}$ following reestablishment of bowel continuity (9.8 $\pm 5.7 \mathrm{yr}$ following the small bowel resection). Patients with SBS had a total oral intake of 2,600 $\pm 715 \mathrm{kcal} /$ day equivalent to $2.0 \pm 0.46$ times their resting energy expenditure (REE). Fecal wet weight was 1,780 \pm 540 g/day (range $800-4,960 \mathrm{~g} /$ day) with a malabsorption of dietary protein, energy, and fat (Table 2). Of 12 patients, nine were PN dependent. BMI was $18.5 \pm 2.4 \mathrm{~kg} / \mathrm{m}^{2}$ with normal albumin 36 $(34-47) \mathrm{g} / \mathrm{l}$ and transthyretin protein 210 (170-300) $\mathrm{mg} / \mathrm{l}$ levels. The CRP was $1(0.2-3.0) \mathrm{mg} / \mathrm{l}$.

The age of controls $(48.5 \pm 15 \mathrm{yr})$ was not significantly different from that of patients with SBS. Mean oral intake was $1,457(900-1,880) \mathrm{kcal} /$ day in controls representing $1.0 \pm$ 0.17 times REE, and BMI was $23 \pm 2 \mathrm{~kg} / \mathrm{m}^{2}$ (Table 2). Oral intake and BMI of patients with SBS were respectively higher and lower $(P<0.001)$ than those of controls.

\section{Morphological Data}

Crypt depth was significantly $(P<0.005)$ increased $(+35 \pm$ $20 \%)$ in the colon of patients with SBS $(n=8,464 \pm 74 \mu \mathrm{m})$ compared with controls ( $n=7,296 \pm 45 \mu \mathrm{m})$ (Fig. 1A). In accordance with this observation, the total number of epithelial crypt cells was also higher $(+22 \pm 16 \%)$ in patients with SBS $(P<0.005)$ than in control group (Fig. 1A). The proliferation rate of the remaining colon in patients with SBS was assessed with Ki67 as a marker of proliferative cells and caspase-3, as a surrogate of apoptosis. The ratio of Ki67-positive cells per crypt was not significantly different in patients with SBS $(n=$ 7 ) and controls $(n=7)$ (Fig. $1 B)$. A complementary analysis by Western blot indicated that PCNA, a protein involved in proliferation, was not modified after resection in the remnant colon (see Supplemental Fig. S1; supplemental material for this article is available at the American Journal of Physiology Gastrointestinal and Liver Physiology website). The apoptotic index was $9.8 \pm 7$ in patients with $\operatorname{SBS}(n=8)$ and $9.2 \pm 3$ in controls $(n=9)$, indicating that the number of caspase-3-

Table 2. Intestinal absorption in patients with SBS and characteristics of controls

\begin{tabular}{|c|c|c|c|c|c|c|c|c|c|c|c|c|c|}
\hline & \multirow[b]{2}{*}{ BMI, $\mathrm{kg} / \mathrm{m}^{2}$} & \multirow[b]{2}{*}{$\mathrm{Kcal} /$ day } & \multicolumn{4}{|c|}{ Oral Intake } & \multicolumn{4}{|c|}{ Absorption } & \multirow[b]{2}{*}{ NP/week } & \multirow[b]{2}{*}{ REE, kcal/day } & \multirow[b]{2}{*}{ Intake/REE } \\
\hline & & & Protein, $g$ & Fat, $g$ & Glucide, $\mathrm{g}$ & Fiber, $\mathrm{g}$ & Total, $\%$ & Protein, $\%$ & Fat, \% & Glucide, $\%$ & & & \\
\hline Patient $(n=12)$ & $18.5 \pm 2$ & $2,600 \pm 715$ & $106 \pm 29$ & $103 \pm 22$ & $302 \pm 110$ & $22 \pm 10$ & ${ }_{\text {Not }}^{53 \pm 16}$ & ${ }_{\text {Not }} 43 \pm 23$ & Not & $\begin{array}{l}88 \pm 11 \\
\text { Not }\end{array}$ & $3.2 \pm 1.8$ & $1,284 \pm 147$ & $2.0 \pm 0.46$ \\
\hline Contol $(n=11)$ & $23 \pm 2$ & $1,457 \pm 75$ & $69 \pm 18$ & $48 \pm 15$ & $182 \pm 32$ & $15 \pm 7$ & Determined & Determined & Detemined & Determined & No & $1,471 \pm 232$ & $1.0 \pm 0.17$ \\
\hline
\end{tabular}

Values are means \pm SD. Oral intake was assessed using Bilnut software. BMI, body mass index; REE, resting energy expenditure; intake/REE, ratio between oral intake (kcal/day) and REE (kcal/day); NP, number of parenteral nutrition infusions per week. 
A
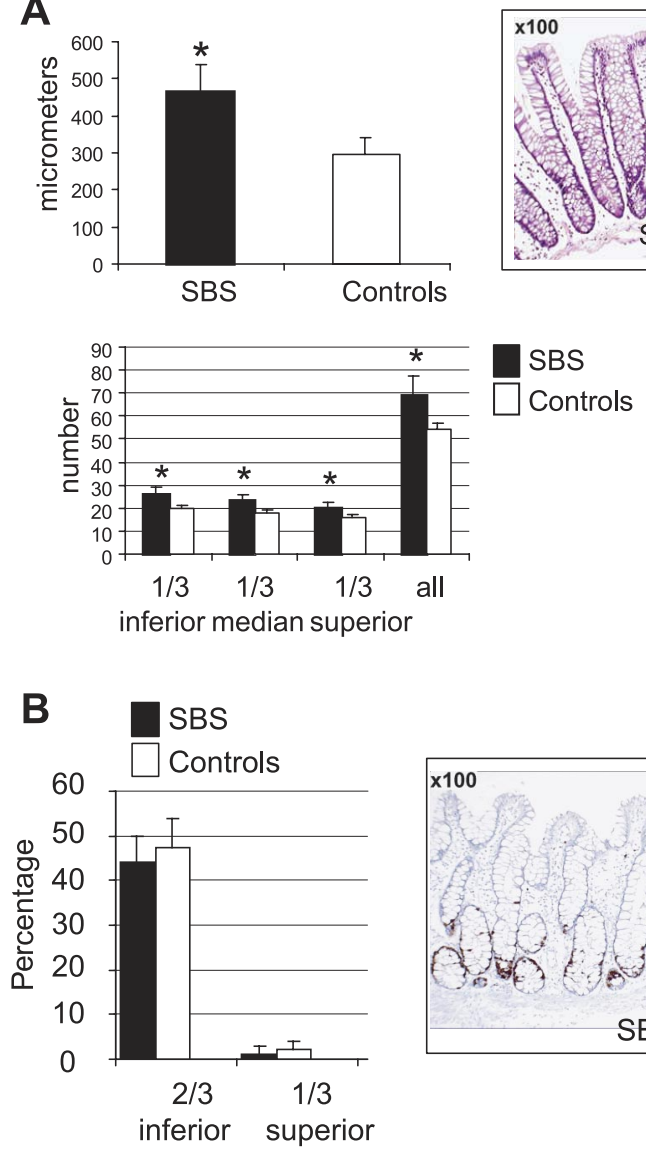

C

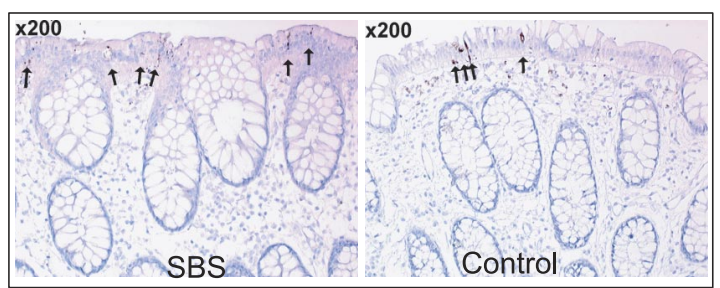

Fig. 1. Morphology in colon of patients with short bowel syndrome (SBS) and controls. A: morphology of colonic mucosa in patients with SBS compared with a control patient (hematoxylin and eosin). The number of cells per crypt was counted on longitudinal hemicrypts divided into 3 equal-sized compartments ( $1 / 3$ inferior, $1 / 3$ median, $1 / 3$ superior). $* P<0.05$. B: percentage of Ki67-positive cells was expressed as a percentage in function of the total number of cells. $C$ : caspase-3-positive cells were quantified as the positive colonic cells observed between 6 crypts (SBS and controls, $n=8$ ). positive cells was equivalent in patients with SBS and in controls (Fig. 1C).

\section{NHE3, NHE2, and PepT1 in the Colon of Patients with SBS and Controls}

To evaluate the transport function of the remnant colon, we sought to analyze three genes, NHE2, NHE3, and PepT1. NHE2 and NHE3 play a major role in sodium and water absorption in the colon $(4,42,54)$, whereas PepT1 is involved in ditripeptide uptake (mainly in the small intestine) (1). These genes were of particular interest because it has been proposed that NHE2, NHE3, and PepT1 were overexpressed after a resection in animal models and in humans $(34,55)$.

Colonic expression hierarchy of NHE3, NHE2, and PepT1 transporters in controls. We determined NHE3, NHE2, and PepT1 expression in the three colonic segments, i.e., proximal, transverse, and distal, of controls (Fig. 2). The hierarchy of colonic expression levels was NHE3 $>$ NHE2 $>$ PepT1. Throughout the anteroposterior gradient, NHE3 was statistically more highly expressed in the proximal colon than in the distal, whereas the opposite gradient of expression was observed for PepT1. NHE2 was equally abundant from the proximal to the distal site.

mRNA of NHE3 and NHE2 exchangers in the colon of patients with SBS and controls. Because we observed that the transporters displayed a site-specific expression throughout the anteroposterior gradient, the level of mRNA was compared between patients with SBS and the control group for each proximal, transverse, and distal location (Fig. 3). The amount of NHE3 mRNA was decreased at the proximal site $(P<0.05)$ in patients with SBS compared with controls, whereas it was not modified at the transverse or the distal sites (Fig. 3). The average of NHE2 mRNA expression level was equivalent in patients with SBS and controls (Fig. 3).

PepT1 mRNA level and protein content in the colon of patients with SBS and controls. The average of PepT1 mRNA expression level was equivalent in patients with SBS and controls (Fig. 3). However, there was a wide variability in the expression of PepT1 mRNA in patients (data not shown). The variability of PepT1 detected at the mRNA level in patients and 


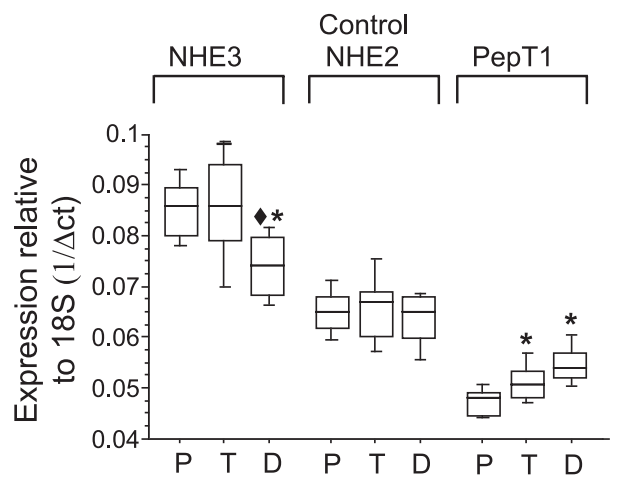

Fig. 2. $\mathrm{Na}^{+} / \mathrm{H}^{+}$exchanger (NHE3 and NHE2) and PepT1 mRNA distribution in the control group. Eight controls ( $\mathrm{C} 1$ to $\mathrm{C} 8$ ) were used for real-time RT-PCR analysis to detect NHE3, NHE2, and PepT1 mRNAs. The values were expressed as an average of $1 / \Delta \mathrm{Ct}[1 /(\mathrm{Ct}$ target gene-Ct18s)]. T, transverse; $\mathrm{P}$, proximal; D, distal site throughout the proximal-distal axis of the colon. - Statistically different from the transverse site $(P<0.05)$, *statistically different from the proximal site $(P<0.05)$.

to a lesser extent in controls, was not reflected at the protein level (Fig. 4A). There was no apparent increase in PepT1 protein in patients (P1, P2, P3, P5, and P6) compared with controls ( $\mathrm{C} 1, \mathrm{C} 2, \mathrm{C} 4$, and $\mathrm{C} 5)$. The PepT1 protein detection system was checked with cell lines and small bowel control samples. As expected, PepT1 was particularly abundant in intestinal cell lines and in the small bowel, whereas it was less abundant in the colon (Fig. 4B).

\section{DISCUSSION}

This study describes a morphological colonic adaptation in a homogenous series of patients with SBS type II (with a jejuno-colonic anastomosis) compared with controls. The adaptive changes included a significant increase in crypt depth and number of cells per crypt. The remnant colon displayed an unchanged proliferative/apoptotic level and well-preserved absorptive NHE2, NHE3, and PepT1 transporter level. This is the first demonstration of controlled hyperplasia in human colonic epithelial cells of patients with SBS.

This series of patients with SBS appears to be representative of patients with SBS type II, with significant small bowel resection associated with severe malabsorption $(31,32)$. Our patients had good nutritional status with no inflammation, confirmed by normal blood CRP, and they displayed hyperphagia $(2,600 \mathrm{kcal} / \mathrm{day})$. Hyperphagia, (oral intake $>1.5$ times REE), has been demonstrated in human adults with postsurgical malabsorption $(11,12,32)$. This oral behavior favors intestinal adaptation by inducing adaptive functional and morphological changes within the gut in animal models $(5,6,8,21$, 29, 30). Patients also had a severe malabsorption with fewer malabsorbed carbohydrates $(88 \pm 11 \%)$ than proteins or lipids. On the basis of the hypothesis that adaptation occurs from $3 \mathrm{mo}$ to $2 \mathrm{yr}$ after bowel continuity was reestablished (35), we evaluated modifications in the remaining colon in hyperphagic patients whose surgery for anastomosis between the jejunum and the remaining colon had been performed at least $2 \mathrm{yr}$ before.

In animal models, an increase in the mucosal mass of the colon has been extensively documented as an adaptive process $(22,34,38,53)$. The present study clearly shows adaptive morphological changes, with significantly deeper crypts
$(+35 \%)$ and increased numbers of cells $(+22 \%)$ per crypt, suggesting that the absorptive surface was increased in the colon after massive and distal small bowel resection. A previous study did not document such morphological changes in the colon of three patients with SBS with type II (jejuno-colonic anastomosis), but the median time since constitution of these patients was less than $2 \mathrm{yr}(50,55)$. In animal models with small bowel resection, the adaptive response is temporally regulated that confirms the importance of studying time (15). Despite a deeper crypt depth, the ratio of proliferative/apoptotic cells to total cells was similar in patients and controls. On the basis of these data, we suggest that an adaptive hyperproliferative process leading to the formation of more cells in
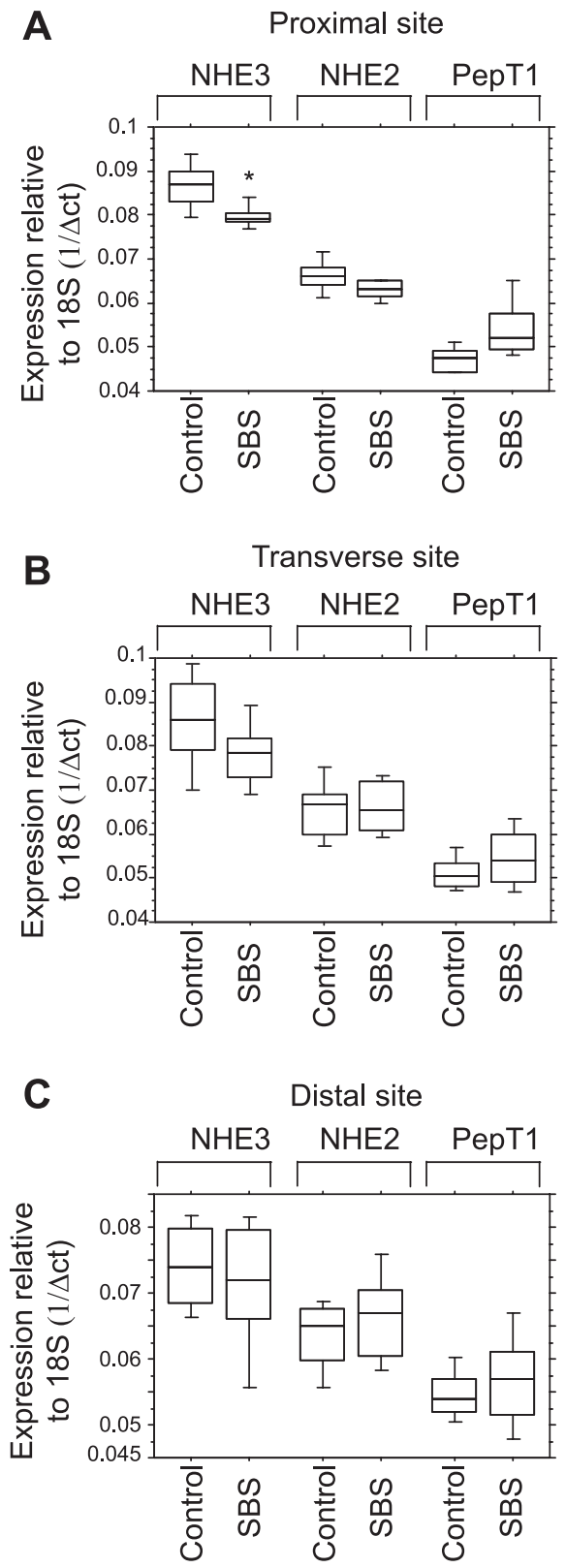

Fig. 3. Similar expression of NHE3, NHE2, and PepT1 mRNA in control group and patients with SBS. NHE3, NHE2, and PepT1 mRNA content was estimated by real-time RT-PCR and expressed as $1 / \Delta \mathrm{ct}[1 /(\mathrm{Ct}$ target geneCt18s)]. $A$ : patients with SBS, $n=6$ and controls, $n=6$; ${ }^{*} P<0.05$. $B$ : SBS $n=10$ and control group $n=8$. $C$ : SBS $n=12$ and control group $n=7$. 


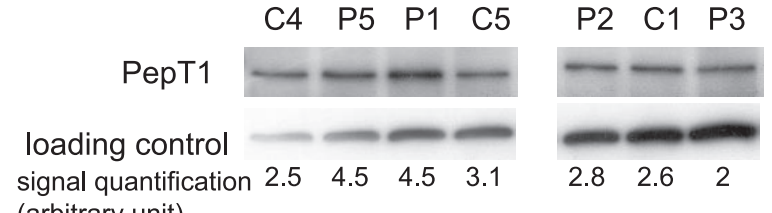
(arbitrary unit)

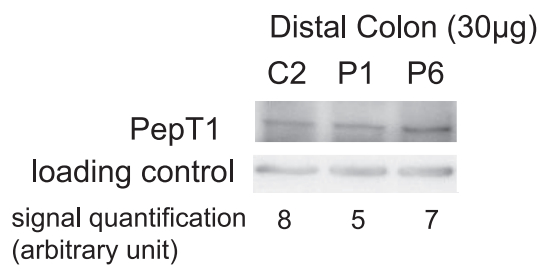

B

$$
\text { C4 }
$$

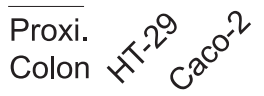

Proteins $(\mu \mathrm{g}) \quad 30 \quad 20 \quad 20$

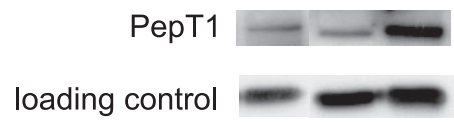

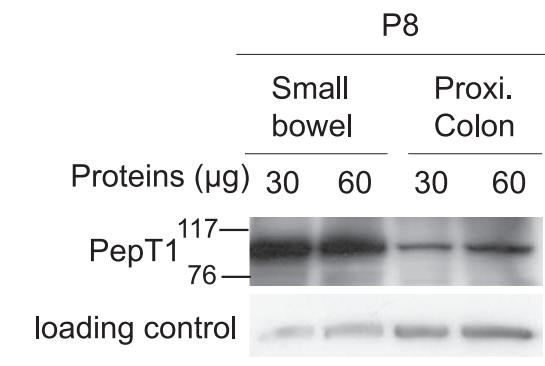

Fig. 4. Equivalent amount of PepT1 protein in patients and in controls. Gels for Western blot were loaded with 20,30 , or $60 \mu \mathrm{g}$ of total proteins as indicated. The membranes were successively hybridized with PepT1 and GAPDH (loading control) antibodies. A: PepT1 detection in biopsies from the proximal and distal sites of the colon from patients with SBS (P1, P2, P3, P5, and P6) and controls ( $\mathrm{C} 1, \mathrm{C} 2, \mathrm{C} 4$, and $\mathrm{C} 5)$. For each lane, the data represented the PepT1 signal divided by the signal of loading control and are expressed as arbitrary units. $B$ : PepT1 detection in 2 cell lines (HT-29 and Caco-2) and in biopsies from small intestine (P8) and colon (P8 and C4). The weight markers indicated that the PepT1 band was detected between 76 and $117 \mathrm{kDa}$. Proxi, proximal. deeper crypt occurred early after the resection and was then compensated with time. The maintenance of a controlled proliferating activity, which we observed at least $2 \mathrm{yr}$ after the resection, is related to personal observation suggesting that patients with SBS have no predisposition to the development of colon cancer (prospective cohort of 22 patients with SBS, median age of $50.9 \mathrm{yr}$ and a follow up to $29 \mathrm{yr}$ ).

During the past $10 \mathrm{yr}$, glucagon-like peptide (GLP)-2 has received attention as a therapeutic agent in the treatment of short bowel in humans. This hormone (secreted by the intestinal L cells in the ileum and the colon) displays pronounced intestinotrophic properties, by increasing mucosal growth, villus height, and water electrolyte absorption in animals (43). In humans with SBS, the administration of [glycine2]-GLP-2 significantly increased in seven patients with SBS type I (end-jejunostomy) villus height, crypt depth, mitotic index, and intestinal function of the remnant small bowel (25). In a recent work, the confirmed enhancement of the small intestine and colon structure with a GLP-2 analog treatment was associated to an unchanged level of the protein content (49). After our demonstration of nonpharmacological colonic hyperplastic adaptation, a better understanding of its mechanisms deserves attention and may lead to the development of targeted treatments in patients with short bowel.

In rats, it has been suggested that colonic upregulation of NHE2 and NHE3 occurs as an adaptation process (34). However, our laboratory did not confirm this overexpression (28). Therefore, the few available data on NHE2 and NHE3 found in animal resection models remain conflicting. For the first time, the expression of NHE2 and NHE3 was studied in the colonic mucosa in humans. The NHE2 mRNA level remained unchanged in patients with type II compared with controls. The
NHE3 mRNA level was slightly decreased at the proximal site and equivalent to that of controls in the transverse and distal sites. This site-specific decrease close to the jejuno-colonic anastomosis could be linked to local extracellular/intraluminal stimuli, such as modifications in osmolarity, luminal foodderived residues such as short chain fatty acids, and glucose or acidification $(16,42)$. Considering the fact that the decreased expression of NHE3 was weak and only observed near the anastomosis, we consider that NHE2 and NHE3 mRNAs remain stable in most of the remaining colon following major small bowel resection. Although the small intestine is the major site of PepT1 expression, it was also detected, to a lesser extent, in the colon (Figs. 2 and 4). Some authors have suggested that PepT1 enhanced expression in the colon is associated with the development of colon injury $(40,45,46)$. Other authors have described PepT1 in the colon of unresected and resected rats (28) and resected and nonresected humans $(17,55)$. Our results provide additional support to the hypothesis that both mRNA but also protein PepT1 are present, though weakly, in the nondiseased human colon.

A previous study described an increase in PepT1 in patients with SBS (55), but in this work we did not observe such an upregulation of PepT1 at mRNA and protein levels. This apparent discrepancy could be linked to the diagnosis of pathology. In our cohort, we excluded patients with an inflammatory disease because PepT1 is involved in the intestinal inflammation activation pathway $(9,14,52)$. None of five subjects (with a remaining colon) sampled by Ziegler et al. (55) had mesenteric ischemia. In addition, we considered only subjects at least $2 \mathrm{yr}$ after resection, whereas Ziegler et al. (55) studied more acute response (several months after the last resection). 
On the basis of the analysis of three transporters (the numbers of transporters was restrained because of a limited amount of biopsies samples), we suggest that the remnant colon keeps stable transport functions in the absence of small bowel. This is in accord with a recent study suggesting that ileal adaptation in a rat model occurs through cellular hyperplasia and not through cellular upregulation of transporters (24).

In conclusion, our study indicates that hyperphagic patients with SBS type II presented in the remaining colon a significant adaptive process characterized by an increased absorptive surface with an unchanged proliferative ratio and stable transporters amount. This is the first demonstration of controlled hyperplasia in human colonic epithelial cells of patients with SBS at least $2 \mathrm{yr}$ after reestablishment of bowel continuity.

\section{ACKNOWLEDGMENTS}

We thank Sophie Rousseau-Penven and Fatima Essafour for dietary assessment. We thank Plateau d'Instrumentation et de Compétences en Transcriptomique (UR1196 Génomique et Physiologie de la Lactation, Institut National de la Recherche Agronomique, Jouy en Josas, France) for help and advice.

\section{GRANTS}

This work was supported by Benjamin Delessert Institut, Nutricia, and Assistance Publique des Hôpitaux de Paris grants.

\section{REFERENCES}

1. Adibi SA. Regulation of expression of the intestinal oligopeptide transporter (Pept-1) in health and disease. Am J Physiol Gastrointest Liver Physiol 285: G779-G788, 2003.

2. Allard JP, Jeejeebhoy KN. Nutritional support and therapy in the short bowel syndrome. Gastroenterol Clin North Am 18: 589-601, 1989.

3. Alpers DH. How adaptable is the intestine in patients with short-bowel syndrome? Am J Clin Nutr 75: 787-788, 2002.

4. Bachmann O, Riederer B, Rossmann H, Groos S, Schultheis PJ, Shull GE, Gregor M, Manns MP, Seidler U. The $\mathrm{Na}+/ \mathrm{H}+$ exchanger isoform 2 is the predominant NHE isoform in murine colonic crypts and its lack causes NHE3 upregulation. Am J Physiol Gastrointest Liver Physiol 287: G125-G133, 2004.

5. Biasco G, Callegari C, Lami F, Minarini A, Miglioli M, Barbara L. Intestinal morphological changes during oral refeeding in a patient previously treated with total parenteral nutrition for small bowel resection. Am J Gastroenterol 79: 585-588, 1984.

6. Bloom SR. Gut hormones in adaptation. Gut 28: 31-35, 1987.

7. Briet F, Flourie B, Achour L, Maurel M, Rambaud JC, Messing B. Bacterial adaptation in patients with short bowel and colon in continuity. Gastroenterology 109: 1446-1453, 1995.

8. Buchman AL, Scolapio J, Fryer J. AGA technical review on short bowel syndrome and intestinal transplantation. Gastroenterology 124: 11111134, 2003.

9. Charrier L, Driss A, Yan Y, Nduati V, Klapproth JM, Sitaraman SV, Merlin D. hPepT1 mediates bacterial tripeptide fMLP uptake in human monocytes. Lab Invest 86: 490-503, 2006.

10. Chomczynski P, Sacchi N. Single-step method of RNA isolation by acid guanidinium thiocyanate-phenol-chloroform extraction. Anal Biochem 162: $156-159,1987$.

11. Cosnes J, Lamy P, Beaugerie L, Le Quintrec M, Gendre JP, Le Quintrec Y. Adaptive hyperphagia in patients with postsurgical malabsorption. Gastroenterology 99: 1814-1819, 1990.

12. Crenn P, Morin MC, Joly F, Penven S, Thuillier F, Messing B. Net digestive absorption and adaptive hyperphagia in adult short bowel patients. Gut 53: 1279-1286, 2004.

13. Cummings JH, James WP, Wiggins HS. Role of the colon in ilealresection diarrhoea. Lancet 1: 344-347, 1973.

14. Dalmasso G, Charrier-Hisamuddin L, Thu Nguyen HT, Yan Y, Sitaraman S, Merlin D. PepT1-mediated tripeptide KPV uptake reduces intestinal inflammation. Gastroenterology 134: 166-178, 2008.
15. Dekaney CM, Fong JJ, Rigby RJ, Lund PK, Henning SJ, Helmrath MA. Expansion of intestinal stem cells associated with long-term adaptation following ileocecal resection in mice. Am J Physiol Gastrointest Liver Physiol 293: G1013-G1022, 2007.

16. Donowitz M, Li X. Regulatory binding partners and complexes of NHE3. Physiol Rev 87: 825-872, 2007.

17. Englund G, Rorsman F, Ronnblom A, Karlbom U, Lazorova L, Grasjo J, Kindmark A, Artursson P. Regional levels of drug transporters along the human intestinal tract: co-expression of ABC and SLC transporters and comparison with Caco-2 cells. Eur J Pharm Sci 29: 269-277, 2006.

18. Erwin CR, Falcone RA Jr, Stern LE, Kemp CJ, Warner BW. Analysis of intestinal adaptation gene expression by cDNA expression arrays. JPEN J Parenter Enteral Nutr 24: 311-316, 2000.

19. Erwin CR, Jarboe MD, Sartor MA, Medvedovic M, Stringer KF, Warner BW, Bates MD. Developmental characteristics of adapting mouse small intestine crypt cells. Gastroenterology 130: 1324-1332, 2006.

20. Falcone RA Jr, Shin CE, Stern LE, Wang Z, Erwin CR, Soleimani M, Warner BW. Differential expression of ileal $\mathrm{Na}(+) / \mathrm{H}(+)$ exchanger isoforms after enterectomy. J Surg Res 86: 192-197, 1999.

21. Feldman EJ, Dowling RH, McNaughton J, Peters TJ. Effects of oral versus intravenous nutrition on intestinal adaptation after small bowel resection in the dog. Gastroenterology 70: 712-719, 1976.

22. Gillingham MB, Dahly EM, Carey HV, Clark MD, Kritsch KR, Ney DM. Differential jejunal and colonic adaptation due to resection and IGF-I in parenterally fed rats. Am J Physiol Gastrointest Liver Physiol 278: G700-G709, 2000.

23. Imbeaud S, Graudens E, Boulanger V, Barlet X, Zaborski P, Eveno E, Mueller O, Schroeder A, Auffray C. Towards standardization of RNA quality assessment using user-independent classifiers of microcapillary electrophoresis traces. Nucleic Acids Res 33: e56, 2005.

24. Iqbal CW, Qandeel HG, Zheng Y, Duenes JA, Sarr MG. Mechanisms of ileal adaptation for glucose absorption after proximal-based small bowel resection. J Gastrointest Surg 12: 1854-1864; discussion, $1864-$ 1865, 2008.

25. Jeppesen PB, Sanguinetti EL, Buchman A, Howard L, Scolapio JS, Ziegler TR, Gregory J, Tappenden KA, Holst J, Mortensen PB. Teduglutide (ALX-0600), a dipeptidyl peptidase IV resistant glucagonlike peptide 2 analogue, improves intestinal function in short bowel syndrome patients. Gut 54: 1224-1231, 2005.

26. Kapel N, Matarazzo P, Haouchine D, Abiola N, Guerin S, Magne D, Gobert JG, Dupont C. Fecal tumor necrosis factor alpha, eosinophil cationic protein and IgE levels in infants with cow's milk allergy and gastrointestinal manifestations. Clin Chem Lab Med 37: 29-32, 1999.

27. Lardy H, Mouille B, Thomas M, Darcy-Vrillon B, Vaugelade P, Blachier F, Bernard F, Cherbuy C, Robert V, Corriol O, Ricour C, Goulet O, Duee PH, Colomb V. Enterocyte metabolism during early adaptation after extensive intestinal resection in a rat model. Surgery 135: 649-656, 2004.

28. Lardy H, Thomas M, Noordine ML, Bruneau A, Cherbuy C, Vaugelade P, Philippe C, Colomb V, Duee PH. Changes induced in colonocytes by extensive intestinal resection in rats. Dig Dis Sci 51: 326-332, 2006.

29. Levine GM, Deren JJ, Steiger E, Zinno R. Role of oral intake in maintenance of gut mass and disaccharide activity. Gastroenterology 67: 975-982, 1974.

30. Levine GM, Deren JJ, Yezdimir E. Small-bowel resection. Oral intake is the stimulus for hyperplasia. Am J Dig Dis 21: 542-546, 1976.

31. Messing B, Crenn P, Beau P, Boutron-Ruault MC, Rambaud JC, Matuchansky C. Long-term survival and parenteral nutrition dependence in adult patients with the short bowel syndrome. Gastroenterology 117: 1043-1050, 1999.

32. Messing B, Pigot F, Rongier M, Morin MC, Ndeindoum U, Rambaud JC. Intestinal absorption of free oral hyperalimentation in the very short bowel syndrome. Gastroenterology 100: 1502-1508, 1991.

33. Miller DS, Payne PR. A ballistic bomb calorimeter. Br J Nutr 13: 501-508, 1959.

34. Musch MW, Bookstein C, Rocha F, Lucioni A, Ren H, Daniel J, Xie Y, McSwine RL, Rao MC, Alverdy J, Chang EB. Region-specific adaptation of apical $\mathrm{Na} / \mathrm{H}$ exchangers after extensive proximal small bowel resection. Am J Physiol Gastrointest Liver Physiol 283: G975G985, 2002. 
35. Nightingale JM, Lennard-Jones JE. The short bowel syndrome: what's new and old? Dig Dis 11: 12-31, 1993.

36. Nightingale JM, Lennard-Jones JE, Gertner DJ, Wood SR, Bartram CI. Colonic preservation reduces need for parenteral therapy, increases incidence of renal stones, but does not change high prevalence of gall stones in patients with a short bowel. Gut 33: 1493-1497, 1992.

37. Nightingale JM, Lennard-Jones JE, Walker ER, Farthing MJ. Jejunal efflux in short bowel syndrome. Lancet 336: 765-768, 1990.

38. Nundy S, Malamud D, Obertop H, Sczerban J, Malt RA. Onset of cell proliferation in the shortened gut. Colonic hyperplasia after ileal resection. Gastroenterology 72: 263-266, 1977.

39. O'Keefe SJ, Haymond MW, Bennet WM, Oswald B, Nelson DK, Shorter RG. Long-acting somatostatin analogue therapy and protein metabolism in patients with jejunostomies. Gastroenterology 107: 379388, 1994.

40. Ogihara H, Saito H, Shin BC, Terado T, Takenoshita S, Nagamachi Y, Inui K, Takata K. Immuno-localization of $\mathrm{H}+$ /peptide cotransporter in rat digestive tract. Biochem Biophys Res Commun 220: 848-852, 1996.

41. Porus RL. Epithelial hyperplasia following massive small bowel resection in man. Gastroenterology 48: 753-757, 1965.

42. Ritter M, Fuerst J, Woll E, Chwatal S, Gschwentner M, Lang F, Deetjen P, Paulmichl M. $\mathrm{Na}(+) / \mathrm{H}(+)$ exchangers: linking osmotic dysequilibrium to modified cell function. Cell Physiol Biochem 11: 1-18, 2001.

43. Rowland KJ, Brubaker PL. Life in the crypt: a role for glucagon-like peptide-2? Mol Cell Endocrinol 288: 63-70, 2008.

44. Sheng G, Bernabe KQ, Guo J, Warner BW. Epidermal growth factor receptor-mediated proliferation of enterocytes requires p21waf1/cip1 expression. Gastroenterology 131: 153-164, 2006.

45. Shi B, Song D, Xue H, Li J, Li N. Abnormal expression of the peptide transporter PepT1 in the colon of massive bowel resection rat: a potential route for colonic mucosa damage by transport of fMLP. Dig Dis Sci 51: 2087-2093, 2006.

46. Shi B, Song D, Xue H, Li N, Li J. PepT1 mediates colon damage by transporting fMLP in rats with bowel resection. J Surg Res 136: 38-44, 2006.
47. Southgate DA, Durnin JV. Calorie conversion factors. An experimental reassessment of the factors used in the calculation of the energy value of human diets. Br J Nutr 24: 517-535, 1970.

48. Stern LE, Falcone RA Jr, Kemp CJ, Erwin CR, Warner BW. p21 (WAF1/CIP1) is required for the mitogenic response to intestinal resection. J Surg Res 90: 45-50, 2000.

49. Tappenden KA, Gilroy R, Allard J, Kunecki M, McGraw N, Sauerwein H, Jeppesen P, Messing B. Teduglutide, a glucagon-like peptide-2 analog, enhances intestinal structure in short bowel syndrome patients dependent on parenteral nutrition (Abstract). Gut 57: A51, 2008.

50. Tavakkolizadeh A, Whang EE. Understanding and augmenting human intestinal adaptation: a call for more clinical research. JPEN J Parenter Enteral Nutr 26: 251-255, 2002.

51. Ukleja A, Tammela LJ, Lankisch MR, Scolapio JS. Nutritional support for the patient with short-bowel syndrome. Curr Gastroenterol Rep 1: 331-334, 1999.

52. Vavricka SR, Musch MW, Chang JE, Nakagawa Y, Phanvijhitsiri K, Waypa TS, Merlin D, Schneewind O, Chang EB. hPepT1 transports muramyl dipeptide, activating NF-kappaB and stimulating IL-8 secretion in human colonic Caco2/bbe cells. Gastroenterology 127: 1401-1409, 2004.

53. Williamson RC, Buchholtz TW, Malt RA. Humoral stimulation of cell proliferation in small bowel after transection and resection in rats. Gastroenterology 75: 249-254, 1978.

54. Yun CH, Tse CM, Nath SK, Levine SA, Brant SR, Donowitz M. Mammalian $\mathrm{Na}+/ \mathrm{H}+$ exchanger gene family: structure and function studies. Am J Physiol Gastrointest Liver Physiol 269: G1-G11, 1995.

55. Ziegler TR, Fernandez-Estivariz C, Gu LH, Bazargan N, Umeakunne K, Wallace TM, Diaz EE, Rosado KE, Pascal RR, Galloway JR, Wilcox JN, Leader LM. Distribution of the $\mathrm{H}+$ / peptide transporter PepT1 in human intestine: up-regulated expression in the colonic mucosa of patients with short-bowel syndrome. Am J Clin Nutr 75: 922-930, 2002. 